\title{
Calendar anomalies in the Turkish foreign exchange markets
}

\section{Kürsat Aydoğan \& G. Geoffrey Booth}

To cite this article: Kürsat Aydoğan \& G. Geoffrey Booth (2003) Calendar anomalies in the Turkish foreign exchange markets, Applied Financial Economics, 13:5, 353-360, DOI: 10.1080/09603100210129457

To link to this article: https://doi.org/10.1080/09603100210129457

册 Published online: 07 Oct 2010.

Submit your article to this journal $\pi$

Џlll Article views: 163

Citing articles: 14 View citing articles $[\pi$ 


\title{
Calendar anomalies in the Turkish foreign exchange markets
}

\author{
KÜRSAT AYDOGAN* and G. GEOFFREY BOOTH
}

Faculty of Business Administration, Bilkent University, Bilkent 06533 Ankara, Turkey and $\$$ Department of Finance, The Eli Broad Graduate School of Management, Michigan State University, USA

This paper investigates calendar anomalies in the Turkish foreign exchange markets during 1986-1994 period. Changes in the free market and official daily exchange rates between the Turkish lira (TL) and US dollar (USD) and the German mark $(\mathrm{DM})$ are examined for empirical regularities on different days of the week, around the turn of the month and before holidays. The findings reveal that free market rates exhibit day-of-the-week and week-of-month effects. In addition free market DM returns display a holiday anomaly. These calendar anomalies are explained by cash disbursement patterns, together with currency substitution in the economy. The impact of treasury auctions and banks' management of liquidity on day-ofthe-week effect is also discussed.

\section{INTRODUCTION}

Calendar anomalies in financial markets are well-documented phenomena. Various studies have found that asset returns are different on days of the week, months of the year, turn of the month and before holidays. Such empirical regularities are more pronounced in securities markets and therefore have been subject to investigation in numerous studies. ${ }^{1}$ Empirical examination of calendar anomalies in foreign exchange markets, on the other hand, has been limited. Nevertheless, the extant studies point out to the presence of a day-of-the-week effect in the spot rates of major currencies as well as traded futures and options on these rates. Key references include McFarland et al. (1982). So (1989), Hilliard and Tucker (1992), and Cornett et al. (1995).

Noticeably absent in the literature is the documentation and explanation of calendar anomalies in the foreign exchange markets of emerging countries. Such an effort is useful because in these economies the foreign exchange market plays a pervasive role. Not only is this market used by those directly involved in international transactions, but also it is used by those who want to hold their assets either in foreign currency dominated deposits or securities. Under these conditions, potential explanations for the existence of calendar anomalies may include, in addition to Ogden's (1990) and Ziemba's (1991) cash flow concentration hypotheses, currency substitution and the related liquidity managements concerns of financial institutions.

The objective of this study is to begin to fill this void by investigating the presence of calendar anomalies in the Turkish foreign exchange market during 1986-1994. Not only is this nine-year period characterized by the existence of an official and a free exchange rate market, but also the foreign exchange regime changed dramatically in August 1989 when the Turkish Lira (TL) was declared a convertible currency. These two phenomena make it possible to analyse more deeply the calendar anomalies of the TL.

\footnotetext{
* Corresponding author: e-mail aydogan@bilkent.edu.tr.

${ }^{1}$ Some of the better known examples on calendar anomalies in the stock markets include Jaffe and Westerfield (1985), Gültekin and Gültekin (1983), Lakonishok and Smidt (1988), and Ziemba (1991).
} 
The specific calendar anomalies investigated are the day-of-the-week (DOW), week-of-the-month (WOM), and holiday (HOL) effects. ${ }^{2}$ The free market and official exchange rates between TL and the US dollar (USD) and the German mark (DM) are used because all of the other currencies contribute little to the volume of Turkish foreign exchange transactions. Exchange rate changes in the free market on Tuesdays and Wednesdays are significantly higher than those in the rest of the week. No such anomaly is encountered for official exchange rates. Free market rates for both currencies also exhibit a significant WOM effect. Daily changes are lower during the last week of a month and they are larger in the first five days, compared to the rest of the month. The HOL effect is only observable in the form of lower free market DM returns before holidays. With respect to the government removing the controls on capital flows, results indicate that the DOW and WOM effects prevailed both before and after the convertibility decision, but with some differences in direction and magnitude.

The remainder of the paper is organized as follows. The institutional framework of Turkish foreign exchange regime is briefly outlined in Section II, and the data are described in Section III. The next three sections are devoted to reporting the respective DOW, WOM and HOL findings. Section VII concludes the paper.

\section{FOREIGN EXCHANGE MARKETS IN TURKEY}

Reforming the foreign exchange regime was the critical part of the Turkish financial liberalization process that started in 1980. ${ }^{3}$ Important milestones prior to 1986 include starting the daily announcement of exchange rates by the Central Bank of Turkey (Central Bank) in 1981, permitting the residents to hold foreign exchange deposits in domestic banks in 1984. During the periods of financial repression, characterized by rigorous controls on foreign exchange and interest rates, most foreign exchange transactions were conducted through the Central Bank at undervalued prices for foreign exchange. The role of commercial banks was highly restricted. A parallel foreign exchange market had developed to assist in other financial transactions, especially those that were either illegal such as payments for some imports, or capital flows. This parallel market, known by the name of the district of Istanbul it was headquartered, Tahtakale, exploited the network of Turkish migrant workers in Western Europe. ${ }^{4}$ Exchange rates on the Tahtakale were determined freely, and were significantly above the official rates. The parallel market suffered a setback in 1984 when banks were allowed to accept foreign exchange deposits and carry out foreign exchange transactions. However, there still was strong demand for foreign exchange from the nonbank public, who could not purchase foreign exchange from commercial banks. For this group, the only source for foreign exchange, which became an instrument of investment, was the parallel market. The next attack on the Tahtakale was the establishment of a Foreign Exchange Interbank market under the auspices of the Central Bank in 1988. With this facility commercial banks that had occasionally entered into transactions using the parallel market could now deal in the interbank foreign exchange market. The final blow to Tahtakale was a series of decrees occurring between August 1989 and March 1990, which resulted in the TL's full convertibility, thereby effectively lifting all restrictions on capital controls for both residents and nonresidents. Banks and other foreign exchange dealers were now able to determine the exchange rates among themselves and a period of floating exchange rates started.

The period after 1990 can be described as one of managed float. The Central Bank continued to announce a daily exchange rate, usually determined in a daily fixing session. The 'official' exchange rate is used in transactions involving the government and serves as a guiding role in the free markets. Free markets, in turn, consist of an interbank market operating under the auspices of the Central Bank and an over-the-counter market of banks and foreign exchange dealers. The latter dominates the free market in terms of size and volume of transaction.

\section{DATA}

The data set used in this study contains daily free market and official exchange rates for the TL in terms of USD and DM. Hereafter, USD (DM) free and official exchange rates are referred to as F-USD (F-DM) and O-USD (O-DM), respectively. All exchange rate series are obtained from the Central Bank. Free market rates are end-of-day ask prices quoted by a major foreign exchange dealer. Official rates are the ask prices announced by the Central Bank for its transactions in foreign exchange. Analysis is conducted on

\footnotetext{
${ }^{2}$ The month-of-the-year effect is not investigated because of the length of the sample period. Nevertheless, the daily exchange rate changes for months of the year was computed. No significant monthly effect was found. There are, however, observable impacts of specific events on some months. For example, the effect of the rapid depreciation of TL in April 1994 is clearly visible in April average, but when 1994 data are removed, there is no 'April anomaly'.

${ }^{3}$ For an in-depth discussion of the financial liberalization process, see Altınkemer and Ekinci (1992). Note that many countries began liberalizing their economies in the 1980 s and within a decade created relatively open economies.

${ }^{4}$ See Olgun (1984) for the role and scope of the black market for foreign exchange in Turkey in that period.
} 
Table 1. Summary of statistics of exchange rate returns

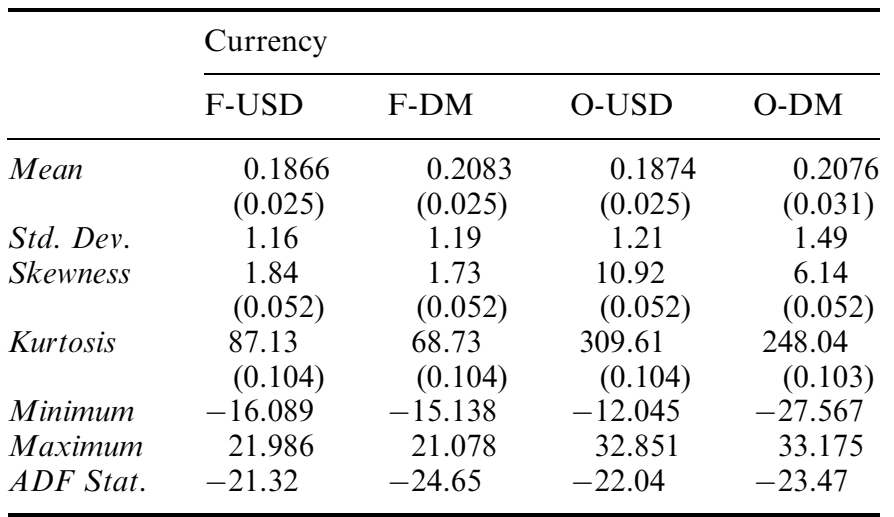

Note: F-USD: Free market USD; F-DM: Free market DM; ODM: O-USD: Official market USD; Official market DM. All exchange rates statistics are for the natural logarithm of the ratio of two consecutive prices. The numbers in parentheses are the standard errors of parameter estimates. ADF Stat. refers to Augmented Dickey Fuller test statistic for unit root on first differences of natural logarithms of foreign currency prices. The critical value for rejecting the null hypothesis of a unit root at $\alpha=0.05$ is -2.86 . ADF tests on unit roots are first performed on the exchange rate levels, measured by the natural logarithm of prices. They indicate that presence of the null hypothesis of a unit root cannot be rejected for all the series.

daily price changes (returns), which are computed as the natural logarithm of the ratio of two consecutive prices. Table 1 presents the summary statistics for the exchange rate returns. All four return series are similar in that they possess positive means, are positively skewed, and thicktailed (compared to a normal distribution). The official series, however, are more skewed and thicker tailed than their free market counterparts. Moreover, as evidenced by the ADF statistic, all four series are mean stationary.

\section{DOW EFFECT}

Turning first to the DOW effect, the following model is estimated for each return series:

$$
R_{t}=\alpha+\beta_{1} D 1_{t}+\beta_{2} D 2_{t}+\beta_{3} D 3_{t}+\beta_{4} D 4_{t}+\varepsilon_{t}
$$

where $R_{t}=$ Return of F-USD, F-DM, O-USD or O-DM,

$D 1_{t}=1$ if $t$ is a Monday, 0 otherwise,

$D 2_{t}=1$ if $t$ is a Tuesday, 0 otherwise,

$D 3_{t}=1$ if $t$ is a Wednesday, 0 otherwise,

$D 4_{t}=1$ if $t$ is a Thursday, 0 otherwise,

$\alpha, \beta_{1}, \beta_{2}, \beta_{3}, \beta_{4}$ are parameters and $\varepsilon_{t}$ is the error term.

The model is estimated for the entire nine-year period, as well as for the two subperiods 1986-1989 and 1990-1994.
By construction of the model, $\alpha$ is the average Friday return, and regression coefficients $\beta_{1}$ through $\beta_{4}$ represent the difference between Friday returns and returns on Monday, Tuesday, Wednesday and Thursday, respectively. Mean returns for each day of the week and the $F$-statistic from the model are presented in Table 2. The $F$-statistics in Table 2 indicate that there is indeed a DOW effect in free market rates during the whole period under examination. This effect is more pronounced in the post-1989 period. In this post-convertibility period, the O-DM exhibits a dayof-the-week effect as well.

To investigate which specific days of the week exhibit weekday anomaly, the mean returns on each day is compared to the mean return of the remaining days and $t$-test is used to determine if the difference is statistically significant. As Ljung-Box Q statistics for autocorrelation indicate the presence of serial correlation in exchange rate return series, Newey and West (1987) heteroscedasticity and autocorrelation consistent covariance matrices are employed in calculating the $t$ statistics. A review of Table 2 reveals that Tuesday and Wednesday returns are higher for the free market rates during the second subperiod, with Tuesday returns being more than twice as large as the overall averages for both the F-USD and F-DM. Friday returns during the post-1989 period in the free market, on the other hand, are lower. ${ }^{5}$

The only weekly economic activity that is strong enough to influence the financial markets is the treasury auction. Starting with mid-1980s, the growing public sector deficit has been financed by government borrowing with the treasury issuing bills and bonds in weekly auctions that started in 1985. As shown in Table 3, the proportion of treasury bills and government bonds among all securities issued hovers between $70 \%$ and $80 \%$ throughout the period.

Banks are the participants of treasury auctions. They purchase government securities for their portfolios as well as for their customers. The specific procedure of auctions can be summarized as follows. The Treasury announces the amount and maturity of the borrowing requirement at the beginning of the week. Banks can submit their bids until 12:00 noon on the day of the auction, which is usually a Tuesday or Wednesday. The Treasury announces the results on the same day, and settlement occurs within two days (Eğilmez 1996: 87-8). The share of government securities in total bank assets, as shown in the second column of Table 3, has been a substantial $10 \%$. Given the sheer size of T-bills in bank asset portfolios and dominating role of government securities in financial markets, auctions of those securities would have a non-negligible impact in all financial markets as well as bank portfolio behaviour.

\footnotetext{
${ }^{5}$ This weekday effect was not found in an earlier study on Turkish foreign exchange markets by Akgiray et al. (1990). However, their data were confined to a shorter period between 1985 and 1987, partially overlapping only with the earliest part of our period of study.
} 
Table 2. Exchange rate changes by the DOW

\begin{tabular}{|c|c|c|c|c|c|c|c|}
\hline Period & Currency & Monday & Tuesday & Wednesday & Thursday & Friday & F-Stat \\
\hline \multirow[t]{6}{*}{ 1986-1994 } & F-USD & $\begin{array}{c}0.1394 \\
(-1.17)\end{array}$ & $\begin{array}{l}0.2459 \\
(1.21)\end{array}$ & $\begin{array}{l}0.2980^{*} \\
(1.96)\end{array}$ & $\begin{aligned} & 0.1798 \\
&(-0.13)\end{aligned}$ & $\begin{array}{l}0.0663 * \\
(-2.70)\end{array}$ & $2.66^{*}$ \\
\hline & F-DM & $\begin{array}{r}0.1369 \\
(-1.71)\end{array}$ & $\begin{array}{l}0.2990 \\
(1.74)\end{array}$ & $\begin{array}{l}0.3165^{*} \\
(2.05)\end{array}$ & $\begin{array}{c}0.1896 \\
(-0.34)\end{array}$ & $\begin{array}{c}0.0991 * \\
(-2.27)\end{array}$ & $2.97^{*}$ \\
\hline & \multirow[t]{2}{*}{ O-USD } & 0.1290 & 0.1500 & 0.2642 & 0.2437 & 0.1480 & 1.19 \\
\hline & & $(-1.12)$ & $(-0.90)$ & $(1.24)$ & (1.07) & $(-0.84)$ & \\
\hline & \multirow[t]{2}{*}{ O-DM } & $0.0794 *$ & 0.2634 & 0.2532 & 0.2750 & 0.1656 & 1.41 \\
\hline & & $(-2.36)$ & $(0.74)$ & $(0.52)$ & $(1.28)$ & $(-0.88)$ & \\
\hline \multirow[t]{8}{*}{ 1986-1989 } & \multirow[t]{2}{*}{ F-USD } & 0.0702 & 0.0230 & $0.2812^{*}$ & 0.2412 & 0.1098 & $2.50^{*}$ \\
\hline & & $(-1.30)$ & $(-1.41)$ & $(2.93)$ & (1.49) & $(-0.70)$ & \\
\hline & \multirow[t]{2}{*}{ F-DM } & $0.398 *$ & 0.1229 & 0.2073 & $0.3337^{*}$ & 0.1888 & 2.17 \\
\hline & & $(-2.49)$ & $(-0.65)$ & $(0.56)$ & $(2.09)$ & $(0.17)$ & \\
\hline & \multirow[t]{2}{*}{ O-USD } & 0.1568 & 0.1378 & 0.1644 & 0.1649 & 0.1194 & 0.19 \\
\hline & & $(0.21)$ & $(-0.16)$ & $(0.55)$ & $(0.44)$ & $(-1.17)$ & \\
\hline & \multirow[t]{2}{*}{ O-DM } & 0.1685 & 0.2533 & 0.0622 & 0.1708 & 0.2320 & 0.44 \\
\hline & & $(-0.13)$ & $(0.44)$ & $(-0.74)$ & $(-0.17)$ & (1.54) & \\
\hline \multirow[t]{8}{*}{ 1990-1994 } & \multirow[t]{2}{*}{ F-USD } & 0.1848 & $0.3915^{*}$ & $(0.390)$ & 0.1401 & $0.0382 *$ & $3.16^{*}$ \\
\hline & & $(-0.53)$ & $(3.25)$ & $(1.09)$ & $(-1.00)$ & $(-2.68)$ & \\
\hline & \multirow[t]{2}{*}{ F-DM } & 0.1994 & $0.4127 *$ & $0.3860 *$ & 0.0985 & $0.0419 *$ & $4.54 *$ \\
\hline & & $(-0.47)$ & (2.98) & (1.99) & $(-1.68)$ & $(-2.61)$ & \\
\hline & \multirow[t]{2}{*}{ O-USD } & 0.1106 & 0.1579 & 0.3295 & 0.2952 & 0.1667 & 1.12 \\
\hline & & $(-1.22)$ & $(-1.00)$ & $(1.16)$ & $(0.99)$ & $(-0.62)$ & \\
\hline & \multirow[t]{2}{*}{ O-DM } & $0.0203^{*}$ & 0.2699 & 0.3783 & 0.3431 & 0.1223 & $2.87^{*}$ \\
\hline & & $(-2.53)$ & $(0.73)$ & $(1.50)$ & (1.43) & $(-1.37)$ & \\
\hline
\end{tabular}

Note: F-USD: Free market USD; F-DM: Free market DM; O-USD: Official market USD; O-DM: Official market DM. The numbers in the body of the table represent daily average changes in a day of the week, expressed as a percentage. F-stat refers to the $F$ statistic obtained from Equation 1. Numbers in parentheses are the Newey-West heteroscedasticity and autocorrelation consistent $t$ statistics for the difference between the daily return and average daily return in the rest of the week.

* indicates significant daily change from the average daily change in the rest of the week at $\alpha=0.05$ level.

Table 3. Summary on government securities, foreign exchange deposits and inflation

\begin{tabular}{llllr}
\hline & $\begin{array}{l}\text { Share of } \\
\text { government securities } \\
\text { in outstanding total } \\
(\%)\end{array}$ & $\begin{array}{l}\text { Share of } \\
\text { government securities } \\
\text { in bank portfolios } \\
(\%)\end{array}$ & $\begin{array}{l}\text { Share of } \\
\text { foreign exchange } \\
\text { deposits in } \\
\text { total deposits }\end{array}$ & $\begin{array}{l}\begin{array}{l}\text { Annual } \\
\text { inflation } \\
(\%)\end{array} \\
\text { Year }\end{array}$ \\
\hline 1986 & 76.80 & 9.46 & 14.1 & 30.34 \\
1987 & 71.70 & 10.22 & 22.7 & 57.29 \\
1988 & 68.60 & 10.59 & 24.8 & 62.50 \\
1989 & 65.90 & 11.68 & 21.2 & 60.04 \\
1990 & 61.10 & 10.49 & 23.8 & 61.99 \\
1991 & 56.40 & 12.47 & 31.5 & 78.50 \\
1992 & 66.70 & 11.25 & 40.3 & 59.77 \\
1993 & 70.20 & 10.60 & 45.6 & 69.65 \\
1994 & 82.40 & 10.91 & 51.9 & 130.60 \\
\hline
\end{tabular}

Note: The first column denotes the percentage of government securities, i.e. T-bills and G-bonds, in total securities outstanding in that year; the second column shows the percentage of government securities in bank asset portfolios, percentage of foreign exchange deposits of residents in total bank deposits are given in column three, and annual inflation, measured as the percentage change in CPI from previous year is present in column four. 
In managing their liquid reserves, banks have a choice between overnight lending in the TL interbank market and foreign exchange. Purchasing T-bills in weekly auctions requires drawing down liquid reserves. Hence they exert a downward pressure on exchange rates on the settlement days of the auctions. On other days, when banks get ready to invest in T-bills, an upward pressure on exchange rates drives the rates up. ${ }^{6}$

\section{WOM EFFECT}

The behaviour of exchange rates during the work weeks around the turn-of-the-month is investigated in this section. ${ }^{7}$ Average daily returns for the last week, first week, second week and the rest of the month are examined. A week is defined as five consecutive business days. Hence, last week of the month comprises of the final five business days of a month; the first five business days make up the first week. The results for the whole period, as well as the two subperiods are displayed in Table 4. For the entire period, free market rates are significantly lower during the week before the turn-of-the-month, and they are higher in the first week. Daily returns in the first week are almost twice as large as the average change in the rest of the days in a month. Moreover, a steady decline in returns from the beginning to the end of a month is observed. Results for the two subperiods are remarkably different. During the 1986-1989 period the only WOM anomaly is the lower exchange rate changes in the last week of the month. First week changes are no different from the rest. In the second subperiod, between 1989-1994, both free market and official returns were significantly higher in the first week.

A plausible economic cause underlying the observed WOM effect is currency substitution, which is the replacement of the traditional functions of domestic currency by foreign currencies. This phenomenon has been documented for many countries experiencing high inflation for extended time periods. Selçuk (1994) shows that the degree of currency substitution in Turkey has been on an increasing trend since it started in mid-1980s. Throughout this period, non-interest bearing TL no longer serve as a store of value or unit of account. Instead many prices are quoted in foreign currencies and price comparisons in different points in time are made in USD or DM. Foreign exchange deposits have largely replaced TL denominated deposits, even interest bearing ones. The third column of Table 3 shows the share of foreign exchange deposits by residents in total bank deposits. Together with higher inflation levels this share has reached 50\% in recent years. Selçuk (1994) notes that 'long queues in front of change offices, especially on days when salaries are paid, suggest that foreign currencies are also replacing Turkish Lira in daily transactions' (Selçuk 1994: 510). In addition, small business firms, with restricted access to interest bearing very short term instruments, also hold their liquid reserves in the form of foreign exchange. In a more recent study, Selçuk (1997) finds that elasticity of substitution between the TL and the USD is indeed very high and significant.

Given the extent of currency substitution in Turkey, it is not surprising to discover that exchange rate changes tend to follow cash disbursement patterns. As Ogden (1990) and Ziemba (1991) point out, standardization of payments may cause them to be concentrated towards the end of the month. There are three major categories of cash disbursements that follow a monthly pattern. These are the salary payments, valued added tax (VAT) payments of business, and payments of social security premiums by employers. Almost all wage income in Turkey is paid as monthly salaries at the beginning of the month. Public servants, who are paid on the fifteenth of the month are a notable exception. ${ }^{8}$ However, their salaries constitute a small fraction in total wage income. Social security premiums, both the employee and employer contributions, are paid to the Social Security Administration by the last day of the month. Likewise, value added taxes paid by consumers on their purchases of almost everything are paid by firms to the tax collection authority by the twenty-fifth day of each month. Both social security premiums and VAT payments are material disbursements of cash. For example VAT revenues made up almost $20 \%$ of the total tax revenues in 1994. When they are taken together, their combined impact on exchange rate changes through currency substitution towards the end of the month is more visible.

Considering the share of foreign exchange deposits by residents in total deposits, currency substitution reached very high levels after 1992. Following the elections in October 1991, the failure of the economic policies of the coalition government to reduce inflation encouraged currency substitution. Shares of foreign exchange deposits climbed to $40 \%$ in 1992 , only to surpass the level of TL

\footnotetext{
${ }^{6}$ Since overnight TL market is the other alternative in liquidity management, one would also consider if there exists a reverse DOW anomaly in overnight interest rates in that market. The presence of a reverse DOW anomaly in overnight interest rates is tested using the available data between 1988-1994. No differences across different days of the week are found. However this finding does not necessarily invalidate the argument behind the DOW effect in free market exchange rates. Because the Central Bank has a firm control over the overnight interbank TL market, which, for that reason, is similar to the official market for foreign exchange. As stated earlier, there are no significant DOW effects in official exchange rates either.

${ }^{7}$ Turn-of-the-year data are included in the analysis since there are no compelling reasons such as taxes to leave them out.

${ }^{8}$ Those public servants do not include workers in government owned firms. Like their counterparts in private firms, those workers are usually paid at the end of the month.
} 
Table 4. Exchange rate changes around the WOM

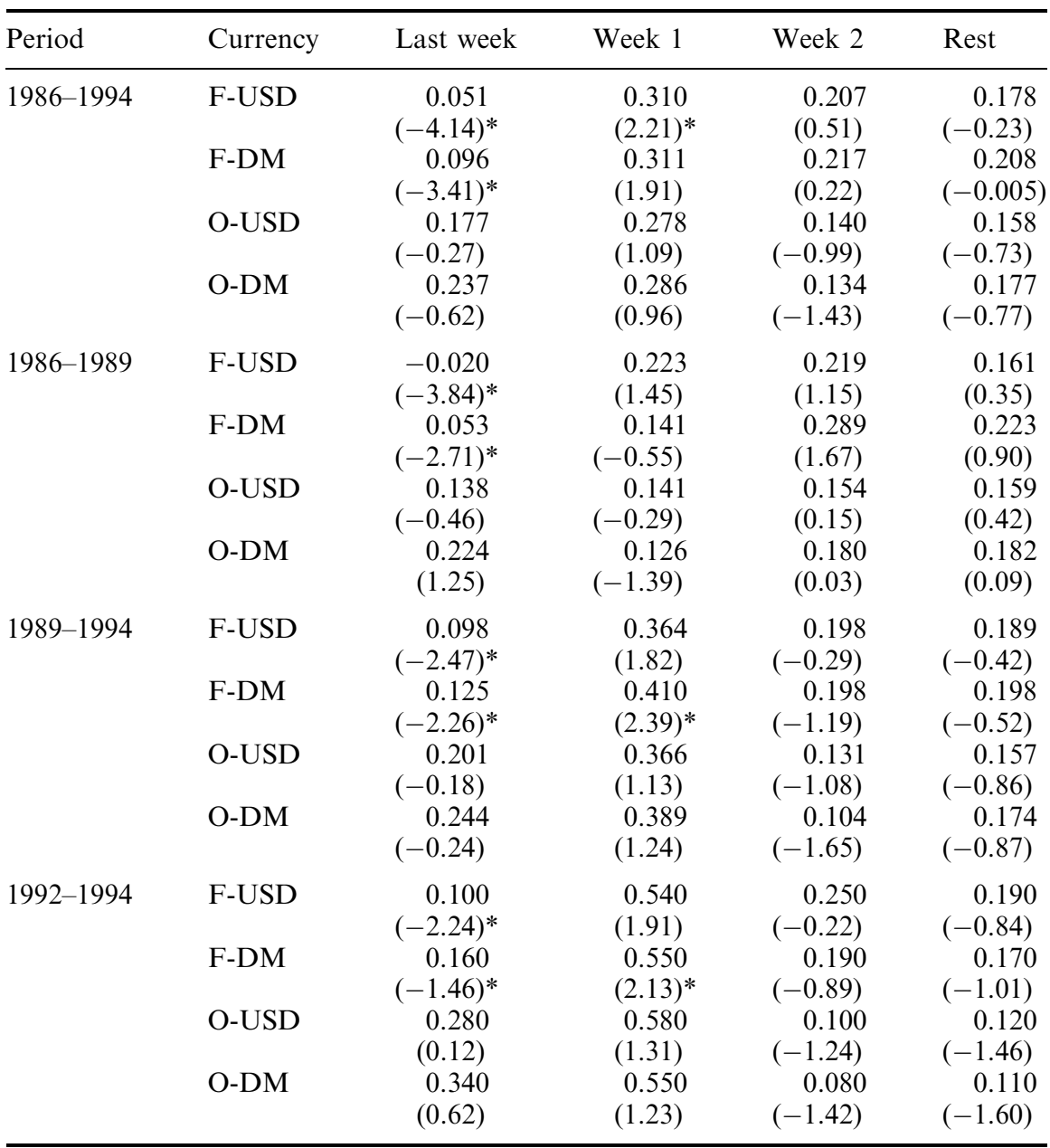

Note: F-USD: Free market USD; F-DM: Free market DM; O-USD: Official market USD; O-DM: Official market DM. The numbers in the body of the table represent daily average changes in a week of the month, expressed as a percentage. The figures in parentheses below average changes are the Newey-West heteroscedasticity and autocorrelation consistent $t$ statistics for the null hypothesis that average daily change in that week is the same as the daily average in the rest of the month.

* indicates significance at $\alpha=0.05$ level.

deposits by the end of 1994. The bottom panel of Table 4 contains the WOM effect results for 1992-1994. As expected, WOM effect is much stronger in this subperiod, with first week changes being three times as large as the changes in the rest of the month. This is true for both currencies in both markets, free and official. ${ }^{9}$

\section{HOLIDAY EFFECT}

The last calendar anomaly investigated is the HOL effect. Individuals and firms who hold foreign exchange may switch to TL just before a holiday for the purposes of shopping, travel, or payment of holiday bonuses. If this proposition is valid, lower exchange rate changes just before the holidays would be observed. During the entire period all holidays that did not start on a weekend are identified and the returns on the day just before the holiday are examined. Between 1986 and 1994 there were 47 such holidays. The findings are presented in Table 5. The average return on preholidays in free market rates are lower, whereas official rates do not exhibit any visible differences. The HOL effect for the F-DM is much is stronger, as evinced by a negative average return on the preholiday,

\footnotetext{
${ }^{9}$ It is also possible, however, that DOW and WOM effects may interact. In other words, when they are combined, the overall effect could be greater or smaller than their sum. To investigate this possibility, a two-way ANOVA analysis is performed. The results, not reported, indicate that main effects are significant, as already demonstrated; but there are no interaction effects.
} 
Table 5. Holiday effect

\begin{tabular}{lccr}
\hline Currency & Preholiday & Other & $t$-stat \\
\hline F-USD & 0.07 & 0.19 & -0.76 \\
F-DM & -0.02 & 0.21 & -2.02 \\
O-USD & 0.19 & 0.19 & 0.01 \\
O-DM & 0.29 & 0.21 & 0.78 \\
\hline
\end{tabular}

Note: F-USD: Free market USD; F-DM: Free market DM; OUSD: Official market USD; O-DM: Official market DM. The numbers in the body of the table represent average daily change in exchange rates, expressed as a percentage. The $t$ statistics are Newey-West heteroscedasticity and autocorrelation consistent.

which shows a statisticallly significant difference from the mean returns on other business days. This is not surprising considering that DM is the preferred foreign currency for wage earners who are engaged in currency substitution behaviour. ${ }^{10}$ Results in the two subperiods (not reported) are not much different: Changes in free market rates are smaller on preholidays compared to the rest of the days.

\section{SUMMARY AND CONCLUSIONS}

Presence of calendar anomalies in Turkish foreign exchange markets are investigated in this paper. Changes in the free market and official daily exchange rates between the TL and USD and the DM are examined for empirical regularities on different days of the week, around the turn of the month and before holidays during the 1986-1994 period. The findings reveal that free market rates exhibit DOW and WOM effects. In addition free market DM returns display a HOL anomaly. Exchange rate changes in free markets on Tuesdays and Wednesdays are significantly higher than other days. A plausible explanation is that treasury auctions taken together with banks' management of their liquid reserves are largely responsible for the interday differences.

Exchange rate changes around the turn of the month exhibit an interesting regularity. They tend to be lower in the week before the turn of the month, after which returns are significantly higher for the first five days of the month. This anomaly may be due to the currency substituting behaviour of individuals and firms for their short term excess cash. A similar argument applies to the preholiday anomaly, which shows itself as lower changes in free market exchange rates before the holidays. All empirical regularities found in this study are confined to free market rates; official rates do not exhibit any calendar anomaly, with the exception of the WOM effect during 1990-1994. ${ }^{11}$ Moreover, calendar anomalies are stronger in the 19901994 subperiod than the 1986-1989 subperiod. This latter period is when the TL appreciated in real terms against foreign currencies, and there was significant capital inflows into the country. Another important feature of the second subperiod was the magnitude of foreign exchange deposits in the banking system. Total value of foreign exchange denominated deposits reached that of TL deposits. This is evidence supporting the notion that foreign exchange became a store of value for short and long term alike, and a cause of the more pronounced WOM effect in the period after convertibility.

\section{REFERENCES}

Akgiray, V., Aydoğan, K., Booth, G. G. and Hatem, J. (1989) A causal analysis of black and official exchange rates: The Turkish case, Weltwirtschaftliches Archiv, 125, 337-45.

Akgiray, V., Aydoğan, K. and Booth, G. G. (1990) The behavior of foreign exchange rates: The Turkish experience, Rivista Internazionale de Scienze Economiche e Commerciali, 38, 169-91.

Altınkemer, M. and Ekinci, N. (1992) Capital account liberalization: The case of Turkey, Central Bank of Turkey Research Department Discussion Paper No. 9210.

Booth, G. G. and Chowdhury, M. (1991) Long-run dynamics of black and official exchange rates, Journal of International Money and Finance, 10, 392-405.

Cornett, M. M., Schwarz, V. and Szakmary, A. C. (1995) Seasonalities and intraday return patterns in the foreign currency futures market, Journal of Banking and Finance, 19, 843-69.

Eğilmez, M. (1996) Treasury, Finans Dünyasi Publications, No. 3, Ankara. (in Turkish).

Gültekin, M. and Gültekin, B. N. (1983) Stock market seasonality: International evidence, Journal of Financial Economics, 12, 469-81.

Hilliard, J. E. and Tucker, A. L. (1992) A note on weekday, intraday, and overnight patterns in the interbank foreign exchange and listed currency options markets, Journal of Banking and Finance, 16, 1159-71.

Jaffe, J. and Westerfield, R. (1985) The weekend effect in common stock returns: International evidence, Journal of Finance, 40, 433-54.

McFarland, J. W., Richardson Pettit, R. and Sung, S. K. (1982) The distribution of foreign exchange price changes: Trading day effects and risk measurement, Journal of Finance, 37, 693-715.

Lakonishok, J. and Smidt, S. (1988) Are seasonal anomalies real? A ninety year perspective, Review of Financial Studies, 1, 403-25.

Newey, W. and West, K. (1987) A simple positive-definite heteroskedasticity and autocorrelation consistent covariance matrix, Econometrica, 55, 703-8.

\footnotetext{
${ }^{10}$ In $1994,70 \%$ of foreign exchange deposits by residents were dominated in DM.

${ }^{11}$ Lack of calendar anomalies in official rates in contrast to free market rates, especially during the earlier period, is consistent with the findings of earlier studies in Turkish foreign exchange markets such as Booth and Chowdhury (1991) and Akgiray et al. (1989). They uncover cointegration and Granger-type causality between free and official rates, none of which contradict the presence of calendar anomalies.
} 
Ogden, J. P. (1990) The turn-of-the-month evaluations of liquid profits and stock returns: A common explanation for the monthly and January effects, Journal of Finance, 45, 125972.

Olgun, H. (1984) An analysis of the black market exchange in a developing economy, Weltwirtschaftliches Archiv, 120, 32947.

Selçuk, F. (1994) Currency substitution in Turkey, Applied Economics, 26, 509-18.
Selçuk, F. (1997) GMM Estimation of currency substitution in a high-inflation economy: Evidence from Turkey, Applied Economic Letters, 4, 225-8.

So, J. C. (1987) The distribution of foreign exchange price changes: trading day effects and risk measurement - A comment, Journal of Finance, 42, 181-8.

Ziemba, W. (1991) Japanese security market regularities: Monthly, turn-of-the-month and year, holiday and golden week effects, Japan and the World Economy, 3, 119-46. 